This is an open access article under the CC BY-NC-ND license (https://creativecommons.org/licenses/by-nc-nd/3.0/) Issue III, November 2020

ISSN 2707-9481

ISBN 978-601-323-207-2

https://doi.org/10.31643/2020.026

\author{
Yesbenbetova Zhanat Halykovna \\ RSE at REM «Republican Research Institute \\ for Labor Protection of the Ministry of Labor \\ and Social Protection of the Population of \\ the Republic of Kazakhstan», \\ Republic of Kazakhstan, Email:nauka@ rniiot.kz \\ ORSID ID: 0000-0002-3966-327X
}

\title{
Methodology for evaluating the effectiveness of the occupational health and safety management system implemented at enterprises
}

\begin{abstract}
The article presents the results of research carried out within the framework of the scientific and technical program in the Republic. As a result of the study, a methodology for evaluating the effectiveness of the occupational health and safety management system implemented at enterprises was developed. We believe that the results of such studies, which determine the innovative system of labor protection management in the Republic of Kazakhstan, along with their application at domestic enterprises, make a great contribution to the development of science and technology in the field of labor protection.

Keywords: occupational safety management system, elements of the occupational safety management system, efficiency assessment, evaluation criteria.
\end{abstract}

Cite this article as: Yesbenbetova Zh. H., (2020). Käsiporındarda engiziligen eñbekti qorğawdı basqarw jüyesiniñ tïimdiligin bağalaw ädistemesi [Methodology for evaluating the effectiveness of the occupational health and safety management system implemented at enterprises]. Challenges of Science. Issue III, p.: 176181. (In Kazakh). https://doi.org/10.31643/2020.026

\author{
Есбенбетова Жанат Халыковна \\ «Қазақстан Республикасы Еңбек және \\ халықты әлеуметтік қорғау министрлігінің \\ еңбекті қорғау жөніндегі республикалық \\ ғылыми-зерттеу институты» ШЖҚ РМК \\ Қазақстан Республикасы, E-mail: nauka@ rniiot.kz \\ ORSID ID: 0000-0002-3966-327X
}

\section{Кәсіпорындарда енгізіліген енбекті қорғауды басқару жүйесінің тиімділігін бағалау әдістемесі}

\footnotetext{
Абстракт. Мақалада республикамызда ғылыми техникалық бағдарлама аясында жүргізілген ғылыми зерттеу жұмыстарының нәтижелері ұсынылған. Зерттеу нәтижесінде кәсіпорындарда енгізілген еңбекті қорғауды басқару жүйесінің тиімділігін бағалау Әдістемесі жасалды. Қазақстан Республикасында еңбекті қорғауды басқарудың инновациялық жүйесін айқындайтын мұндай зерттеулер нәтижесін отандық кәсіпорындарда
} 
қолданумен қатар, еңбекті қорғау саласындағы ғылым және технологияларды дамытуға үлкен үлесін қосады деп есептейміз.

Тірек сөздер: еңбекті қорғауды басқару жүйесі, еңбекті қорғауды басқару жүйесінің элементтері, тиімділікті бағалау, бағалау критерийлері.

Еңбекті қорғауды басқару жүйесінің (әрі қарай- ЕҚБЖ) маңызды қағидаты тұрақты даму және жетілдіру болып табылады, ол, өз нәтижесінде, еңбек жағдайларының сапасын арттыруға және жұмыскерлер арасындағы өндірістік жарақаттану мен кәсіби науқастану деңгейін төмендетуге, олармен байланысты экономикалық шығындарды азайтуға, заңнама талаптарының сақталуын қамтамасыз етуге, мемлекеттік мониторинг пен бақылауға жәрдемдесуге тиіс.

Осыған байланысты, Қазақстан Республикасы Еңбек және халықты әлеуметтік қорғау министрлігінің Еңбекті қорғау жөніндегі республикалық ғылыми-зерттеу институты (әрі қарай-ҚР ЕХӘҚМ ЕҚРҒЗИ), «Қазақстан Республикасы экономикасының басым секторларында қауіпсіз еңбекті қамтамасыз етудің ғылыми-әдістемелік негіздерін әзірлеу» тақырыбында ғылыми - техникалық бағдарлама (бұдан әрі-ҒТБ) бойынша ғылыми зерттеулер (ИРН 61897/ПЦФ-МТСЗН РК-ОТ-20) жүргізді. Зерттеу жұмыстары 3 кезеңнен (2018-2020 жж.) тұрды.

ҒТБ іске асыру алдыңғы қатарлы ғылыми тәсілдерді, қауіпсіз еңбекті қамтамасыз етудің тиімді тетіктерін көрсететін ұлттық бағдарламаны, еңбекті қорғауды басқару саясаты мен жүйесін айқындауға бағытталған. Еңбекті қорғауды басқарудың жаңа моделі нарықтық экономиканың қазіргі заманғы болмысына жауап береді және еңбекті қорғауды жетілдіруге, өндірістік жарақаттану жағдайларының алдын алуға жәрдемдеседі. Ұсынылып отырған ғылыми негізделген жаңалықтар негізінде еңбекті қорғау саласындағы отандық нормативтік құқықтық базаны Халықаралық еңбек ұйымының конвенцияларының талаптарымен және Экономикалық ынтымастық мен даму ұйымы мен Еуразиялық экономикалық одақ елдерінде қолданылатын практикамен үйлестіруге бағытталған тәсілдер пайдаланылды.

Сонымен қатар, зерттеу барысында анық болғандай, қазіргі кезеңде кәсіпорындарды басқаруды жетілдіру ИСО 9000, ИСО 14000, ИСО 45001, OHSAS 18000, ANSI Z10 және т. б. халықаралық стандарттар негізінде менеджмент жүйелерін енгізумен байланысты екені анықталды. Бұл құжаттарда сапаны, экологияны, еңбекті қорғауды және кәсіби қауіпсіздікті жүйелі басқарудың әлемдік тәжірибесі жинақталған. Өкінішке орай, ҚР көптеген өнеркәсіптік кәсіпорындарында еңбекті қорғауды басқару жүйелерін енгізу, оларды енгізу мен қамтамасыз етуге жұмсалатын елеулі шығындарға қарамастан (олардың басым бөлігі сертификаттау және сыртқы аудит рәсімдеріне негізделген) тиімділікті көрсеткен жоқ. Олар іс жүзінде белсенді емес, бұл өндірістік тәртіптің төмендеуіне, қауіпсіздік шараларын жеткіліксіз материалдық-техникалық және қаржылық қамтамасыз етуге, сондай-ақ көптеген бұзушылықтарға әкеледі. Бұдан басқа, ішкі және сыртқы аудиттер, өлшеу, талдау, өзін-өзі бағалау талаптары, түзету және алдын алу іс-әрекеттері, тұтынушылармен кері байланыс, қызметті үздіксіз жақсарту түріндегі ЕҚЖБ стандарттарына енгізілген тетіктер көбінесе үстіртін, формальды сипатта болады [7]. Кәсіпорында жүргізілетін процестердің, рәсімдердің, ұйымдастыру құрылымы мен ресурстардың стандарттар талаптарына сәйкестігін растайтын немесе сәйкессіздігін анықтайтын ішкі аудиттер олардың жұмыс істеу немесе пайдалану тиімділігін аз ғана дәрежеде бағалай алады [10]. Бұл ішкі аудиттердің мезгіл-мезгіл, жүйенің жеке элементі немесе кез-келген бөлімде іріктеп жүргізілетіндігіне байланысты. Сондықтан олар ЕҚБЖ жұмыс істеу тиімділігін жалпы, жүйелі бағалауды қамтамасыз ете алмайды.

Үшінші нормативтік-талдау кезеңі (2020 ж.) барысында пилоттық кәсіпорындарда ЕҚБЖ енгізудің тиімділігіне бағалау жүргізілді. Оны жүргізу үшін критериалды тәсілге негізделген авторлық әдістеме жасалды. Кәсіпорындарда енгізілетін әртүрлі жүйелердің тиімділігін бағалаудың ұсынылған критерийлері зерттелді, оның ішінде еңбекті қорғауды ұйымдастыруға және осы саладағы нормативтік талаптарды сақтауға бағытталған атап айтсақ, авторлар А. Н. Никулин және И. И. Должиков [13], Е. А. Кузнецова және Т. В. Михина [8], А. А.Стариков, У.А. Хлесткова [15], D. Podgorski [2], L. Robson, S. Ibrahim, Sh.Hogg-Johnson [3] және т. б.,- өз еңбектерінде кеңінен зерттеген. Сондай-ақ, ЕҚБЖ белгіленген талаптарға сәйкестігін бағалау әдістемесі (еңбекті қорғау саласындағы аудит немесе сараптама түрінде және т. б.) В. А. Филимоновтың және Л. Н. Горинаның [16], А. М. Елиннің [5], Р. И. Макаровтың [10], Е. Р. Хорошеваның, С. А. Огрызковтың [11], А. К. Логиновтың, Г. В. Ляховскийдің, И. Л. Кравчуктың [9] және т. б. жұмыстарында ұсынылатын ғылыми - әдістемелік тәсілдердің критерийлері мен талдауларының негізінде әзірленген. 
Осы мәселені шешудің қазіргі заманғы деңгейін талдау жүйенің алдына қойылған мақсаттарға қол жеткізу дәрежесін бағалауға негізделген тәсілдемелердің, әдетте, нысаналы индикаторлардың көмегімен (KРI әдісі), қойылған мақсатқа қол жеткізудің әртүрлі процестерін (траекториясын) бағалау мен салыстыруда болуын көрсетті [17]. Сонымен қатар, индикаторларды (KPI және т.б.) қолдану олардың субъективтілігіне байланысты, өйткені оларды ЕҚЖБ ұйымдастырушысы айқындайды, сондай-ақ оларды тиісті деңгейде ұстап тұру мүмкіндігіне байланысты (жарақаттардың болмауы, еңбек жөніндегі мемлекеттік инспекция нұсқамаларының болмауы және т. б.) және бұл ретте жүйені жетілдірмей, тиімсіз деп санаймыз.

Авторлар А. Н. Никулин және И.С. Должиков өз зерттеулерінде 16 критерийлерді ұсынады (еңбекті қорғау тақырыптары бойынша персоналға жүргізілген сауалнамалардың болуы, аяқталған ішкі тексерулер (аудиттер) санының жоспарланған тексерістер санына қатынасы; «дерлік оқиғаларды» тіркеу/саны, сәйкестендірілген және жойылған тәуекелдер санының қатынасы және т. б.) және осы критерийлердің болуы немесе болмауы ғана емес, сондай-ақ, оларды орындау деңгейі мен бақылау кезеңділігі [13] маңызды деп таниды. А. В. Стариков, У. А. Хлесткова және бірқатар басқа авторлар критерийлерді объективті (өлім жазатайым оқиғаларының саны, жарақаттанудың жиілігі мен ауырлығының коэффициенттері, оқыс оқиғалар саны) және субъективті (кәсіби тәуекелдің деңгейі, еңбек жағдайларының әрбір сыныбы бойынша жұмыс орындарының саны, персоналдың жеке қорғаныс құралдарымен қамтамасыз етілуі, еңбек жағдайларын жақсартуға арналған шығыстардың шамасы, персоналдың қауіпсіздік ережелеріне оқытылуы, әкімшілік-қоғамдық бақылау жүйесінің пәрменділігі және т.б.) деп жіктейді [15], [14]. Авторлар оптимизм критерийлерін және оларды есептеу әдістерін таңдаудағы негізгі қиындықтарды, әрдайым үйлесімді емес және кейде қайшылықты емес көптеген критерийлердің болуын мойындайды. Сондықтан негізгі және өте қиын міндетоңтайлылықтың жалпыланған өлшемдерін қалыптастыру болып табылады. Кейбір жағдайларда тиімділіктің жалпыланған көрсеткіші таңдалған жеке критерийлер жүйесінде аддитивті және мультипликативті қайта құру негізінде құрылады.

ЕҚБЖ, кез келген жүйеленген қызмет саласы сияқты, іске асырылған міндеттер мен рәсімдер күтілетін нәтижеге қаншалықты әкелгенін анықтауға мүмкіндік беретін оның тиімділігіне тұрақты немесе мерзімді мониторинг ұйымдастыруды талап етеді. Авторлардың пікірінше, [4] жүйе формальды түрде басқару объектісі, басқару әсері (басқару жүйесі), кіріс, шығыс, ақпарат ағындары (байланыс жүйесі) сияқты элементтер жиынтығынан тұрады. Ұйымдағы еңбекті қорғау басқару объектісі ретінде қарастырылады. Кіріс және шығыс деректері сәйкесінше сыртқы әсерді (әр түрлі кедергілер) және басқару объектісінің сапасы мен тиімділігін сипаттайтын көрсеткіштерді анықтайды. ЕҚБЖ сапасына және оның тиімділігіне әсер ететін өлшенетін шарттар, көрсеткіштер және факторлар басқару объектісінің жай-күйі туралы ақпаратты қалыптастырады.

Әдістемені құрудың әдіснамалық негізі олардың объективтілігін, қол жетімділігін, салыстырмалылығын ескере отырып, өлшемдерді, көрсеткіштерді және деректерді өңдеу тәсілін таңдау болып табылады. Осыған байланысты көрсеткіштер олардың кәсіпорын статистикасындағы дұрыстығын ескере отырып анықталды (есептілік нысандары, есепке алу журналдары, штат кестесі, еңбекті қорғау және еңбек қауіпсіздігі саласындағы жұмыс берушінің актілері және т.б.). Салыстырмалылық көрсеткіштерді пайдалану арқылы қамтамасыз етіледі, ол үшін тиімділік критерийлері негізінде жүйенің қол жеткізу дәрежесін, сыналатын ЕҚБЖ белгіленген рәсімдеріне кіретін нормативтік регламенттелген нысаналы индикаторларды бағалауға мүмкіндік беретін тәсіл қолданылады.

Осылайша, ғылыми зерттеулер барысында бағалау критерийлері мен көрсеткіштерін қалыптастыруға әсер ететін факторларды ескере отырып, критерийлерге топтастырылған және олардың мәнін ашатын негізгі белгілердің (көрсеткіштердің) белгілі бір саны жиналатын, Тіркелетін және талданатын жүйенің мониторингін пайдалана отырып, кәсіпорындағы ЕҚБЖ жай-күйін анықтауды жүзеге асыру қабылданды. Зерттеу жұмыстары кезінде таңдалып алынған экономиканың әр түрлі салаларындағы 20 кәсіпорындарына арналып әзірленген және сыналған ерекшеліктерді ескере отырып, ЕҚБЖ критерийлер жиынтығы жасалды. Бұл жиынтық енгізілетін ЕҚБЖ барлық аспектілерін қамтитын бес критерийден тұрады:

- ЕҚБЖ элементтері рәсімдерінің уақыттылы орындалуы;

- ЕҚБЖ элементтерінің процедураларын орындау сапасы;

- ЕҚБЖ элементтері рәсімдерінің орындалуын бақылау;

- кәсіби тәуекелдерді басқарудың тиімділігі [6];

- экономикалық тиімділігі. 
Бұл критерийлер жүйенің жай-күйін, атап айтқанда рәсімдерді іске асырудың уақыттылығын, сапасы мен нәтижелілігін сипаттауға қабілетті 25 көрсеткішті қорытындылайды.

ЕҚБЖ жұмыс істеу тиімділігін бағалау үшін мыналарды: бағалау объектісі (Жалпы жүйе); жүйенің жұмыс істеу тиімділігін бағалау критерийлері; жүйенің жұмыс істеу тиімділігінің көрсеткіштерін тиімділік өлшемдерімен бағалау және салыстыру тәсілі; алынған нәтижелерді статистикалық талдау әдістерін анықтауы қажет.

Әр критерий үшін бірқатар көрсеткіштер жасалды. Әрбір критерийді қалыптастыратын көрсеткіштер әртүрлі тәсілдермен (есептеу формулаларын, теңдеулерді, баллдарды тағайындауды қолдана отырып) есептелетін сандық мән негізінде айқындалады. ЕҚБЖ тиімділігін қорытынды бағалау барлық өлшемдер бойынша орташа мәнді шығару жолымен жүргізіледі. Әрбір критерий бойынша бағалау нәтижелері тиімділік көрсеткішіне сәйкес бөлінеді $\left(\sum N_{\Pi}^{i}\right)$. Тиімділік дәрежесі пайыздық мәнге байланысты төмендегідей сараланады:

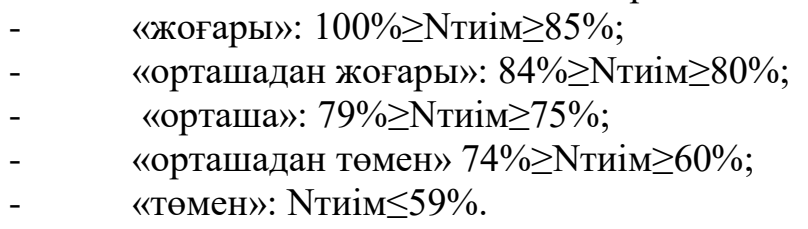

Есептеулерге арналған деректерінен басқа, заңнаманы қандай бұзушылықтарға немесе қандай ЕҚБЖ рәсімдерді сақтамауға байланысты тиімділіктің төмендегі туралы ақпарат енгізу көзделген ЕҚБЖ тиімділігін бағалау Хаттамаларының нысандары әзірленді. Ғылыми іссапарлар барысында әдістеме талаптарына сәйкес пилоттық кәсіпорындарда деректерді жинау жүргізілді және көрсеткіштерді есептеу жүзеге асырылды, деректерді статистикалық өңдеу және кәсіпорын деңгейінде интеграцияланған ЕҚБЖ тиімділігін талдау жүргізілді.

Кәсіби тәуекелдер негізінде ЕҚБЖ тиімділігін бағалау Әдістемесіне авторлық құқықтарды мемлекеттік тіркеу туралы куәлікпен расталды [12].

Қорыта келе айтарымыз, тиімділікті бағалау нәтижелері бойынша барлық пилоттық кәсіпорындар үшін түзету сипатындағы ұсынымдардан тұратын есептер қалыптастырылды. Ұсыныстар арасында ЕҚБЖ жай-күйіне жыл сайынғы ішкі аудит жүргізу және түзету іс-әрекеттерінің тиімділігін анықтау үшін әзірленген әдістемені қолдану болды. Кәсіпорын басшылары осы есептерді келісіп, назарға алды, ЕҚБЖ-нің белгіленген талаптарға сәйкестігін бағалау әдістемесін енгізу туралы актілерге қол қойылды.

Мақалаға сілтеме: Есбенбетова Ж. Х. (2020) Кәсіпорындарда енгізіліген еңбекті қорғауды басқару жүйесінің тиімділігін бағалау әдістемесі. Challenges of Science. Issue III, p.: 176-181. https://doi.org/10.31643/2020.026

\section{Әдебиеттер}

[1] Anna Skład Assessing the impact of processes on the Occupational Safety and Health Management System's effectiveness using the fuzzy cognitive maps approach. Safety Science Volume 117, August 2019, Pages 71-80

[2] Daniel Podgórski Measuring operational performance of OSH management system - A demonstration of AHP-based selection of leading key performance indicators. Safety Science. Volume 73, March 2015, pp. 146-166.

[3] Lynda Robson, Selahadin Ibrahim, Sheilah Hogg-Johnson Developing leading indicators from OHS management audit data: Determining the measurement properties of audit data from the field. Journal of Safety Research Volume 61, June 2017, pp. 93-103

[4] Волкова Н.В., Ефимова Е.И. Мониторинг функционирования системы управления охраной труда // Вестник евразийской науки. 2013. №1 (14). 67 стр. URL: https://cyberleninka.ru/article/n/monitoring-funktsionirovaniya-sistemyupravleniya-ohranoy-truda (дата обращения: 02.10.2020)

[5] Елин А.М. Социально-экономическая оценка эффективности управления охраной труда // Уровень жизни населения регионов России. 2016. №2 (200). С. 104-111. URL: https://cyberleninka.ru/article/n/sotsialnoekonomicheskaya-otsenka-effektivnosti-upravleniya-ohranoy-truda (дата обращения: 30.09.2020).

[6] Есбенбетова Ж. Х. (2019) Керамикалық кірпіш өндіруші кәсіпорындағы еңбекті қорғауды басқару жүйесін талдау. «Ғылымның өзекті мәселелері» - Халықаралық практикалық интернет- конференция материалдары / Materials of International Practical Internet Conference "Challenges of Science”. ISBN 978-601-323-144-0. Басылым II, 2019. Бет: 55-59. https://doi.org/10.31643/2019.009 


\section{Materials of International Practical Internet Conference "Challenges of Science"}

[7] А.Б. Ибраева, Н.С. Медеубаева, Р.И. Маменова Қыш кірпіш кәсіпорындарына еңбекті қорғауды басқару жүйесінің тиімділігін бағалау әдісін сынақтан өткізу// Вестник Каз АТК 2020. №3. С.109-104

[8] Карпиков В. И. Как оценить эффективность функционирования системы качества? / Век качества, № 3. - Век качества, 2001. - С.10-11

[9] Кузнецова Е.А., Михина Т.В. Методологические подходы к формированию рейтинга по уровню соблюдения трудового законодательства // Евразийский Союз Ученых. 2017. №10-2 (43).

[10] Логинов А. К., Ляховский Г. В., Кравчук И. Л. Подходы к оценке эффективности функционирования системы управления промышленной безопасностью // Горный информационно-аналитический бюллетень (научнотехнический журнал), vol. 3, №12, 2007, - С. 138-147.

[11] Макаров Р. И., Хорошева Е. Р., Огрызков С. А. Методика анализа и оценки эффективности функционирования системы менеджмента в области профессиональной безопасности и охраны труда // Труды Международного симпозиума «Надежность и качество», vol. 1, 2005, pp. 472-475. URL: https://cyberleninka.ru/article/n/metodikaanaliza-i-otsenki-effektivnosti-funktsionirovaniya-sistemy-menedzhmenta-v-oblasti-professionalnoy-bezopasnosti-iohrany-truda (дата обращения: 02.10.2020)

[12] Макаров Р. И., Хорошева Е. Р., Орызков С. А. Методика анализа и оценки эффективности функционирования системы менеджмента в области профессиональной безопасности и охраны труда // Труды Международного симпозиума «Надежность и качество», НиКа. 2005. №. 1. С. 472-745. URL: https://cyberleninka.ru/article/n/metodikaanaliza-i-otsenki-effektivnosti-funktsionirovaniya-sistemy-menedzhmenta-v-oblasti-professionalnoy-bezopasnosti-iohrany-truda (дата обращения: 30.09.2020).

[13] Методика оценки эффективности функционирования интегрированной системы управления охраной труда на основе управления профессиональными рисками (научное произведение) / Авторы: Бисакаев С.Г., Джумагулова Н.Г., Есбенбетова Ж.Х., Танабаева А.Е., Айткенова Г.Т. / Св.9304 от «17» апреля 2020г.

[14] Никулин А.Н., Должиков И.С. Критерии оценки эффективности функционирования системы управления охраной труда // Проблемы Науки. 2017. №7 (89).

[15] Пустовит А.Е., Козлов В. И. Методика расчета индекса безопасности труда // Вестник КузГТУ. 2013. №3. С. 65-68. URL: https://cyberleninka.ru/article/n/metodika-rascheta-indeksa-bezopasnosti-truda (дата обращения: 30.09.2020)

[16] Стариков А.В., Хлесткова У.А. Комплексные критерии оценки эффективности сложных систем организационного управления охраной труда и промышленной безопасностью // Инновационная наука. 2015. №9. С. 97-99. URL: https://cyberleninka.ru/article/n/kompleksnye-kriterii-otsenki-effektivnosti-slozhnyh-sistem-organizatsionnogoupravleniya-ohranoy-truda-i-promyshlennoy-bezopasnostyu (дата обращения: 30.09.2020).

[17] Филимонов В.А., Горина Л.Н. Особенности разработки системы управления охраной труда на основе процессного подхода // Записки Горного института. 2019. №. URL: https://cyberleninka.ru/article/n/osobennosti-razrabotki-sistemyupravleniya-ohranoy-truda-na-osnove-protsessnogo-podhoda (дата обращения: 30.09.2020).

\section{References}

[1] Anna Skład Assessing the impact of processes on the Occupational Safety and Health Management System's effectiveness using the fuzzy cognitive maps approach. Safety Science Volume 117, August 2019, Pages 71-80. (In English).

[2] Daniel Podgórski Measuring operational performance of OSH management system - A demonstration of AHP-based selection of leading key performance indicators. Safety Science. Volume 73, March 2015, pp. 146-166. (In English).

[3] Lynda Robson, Selahadin Ibrahim, Sheilah Hogg-Johnson Developing leading indicators from OHS management audit data: Determining the measurement properties of audit data from the field. Journal of Safety Research Volume 61, June 2017, pp. 93-103. (In English).

[4] Volkova N.V., Yefimova Ye.I. Monitoring funktsionirovaniya sistemy upravleniya okhranoy truda [Monitoring the functioning of the OSH management system] // Vestnik yevraziyskoy nauki. 2013. №1 (14). 67 str. URL: https://cyberleninka.ru/article/n/monitoring-funktsionirovaniya-sistemy-upravleniya-ohranoy-truda (data obrashcheniya: 02.10.2020). (In Russian).

[5] Yelin A.M. Sotsial'no-ekonomicheskaya otsenka effektivnosti upravleniya okhranoy truda [Socio-economic assessment of the efficiency of labor protection management] // Uroven' zhizni naseleniya regionov Rossii. 2016. №2 (200). S. 104-111. URL: https://cyberleninka.ru/article/n/sotsialno-ekonomicheskaya-otsenka-effektivnosti-upravleniya-ohranoy-truda (data obrashcheniya: 30.09.2020). (In Russian).

[6] Yesbenbetova ZH. KH. (2019) Keramikalyk, kírpísh endírushí kəsíporyndaġy уеңbektí k,orgaady bask,aru zhyyyesín taldau. «Ġylymnyн ezektí məselelerí» - Khalyk, aralyk, praktikalyk [(2019) Analysis of the health and safety management system at the ceramic brick factory] / Materials of International Practical Internet Conference "Challenges of Science". ISBN 978-601-323-144-0. Basylym II, 2019. Bet: 55-59. (In Kazakh). https://doi.org/10.31643/2019.009

[7] A.B. Ibrayeva, N.S. Medeubayeva, R.I. Mamenova K, ysh kírpísh kəsíporyndaryna yeңbektí k, orgaaudy bask, aru zhyyyesíní tiímdílígín bagalau ədísín synak, tan etkízu [Testing the method of assessing the effectiveness of occupational safety management systems for brick and mortar enterprises] // Vestnik Kaz ATK 2020. №3. S.109-104. (In Kazakh).

[8] Karpikov V. I. Kak otsenit' effektivnost' funktsionirovaniya sistemy kachestva? [Methodological approaches to the formation of the rating according to the level of compliance with labor legislation] / Vek kachestva, № 3. - Vek kachestva, 2001. - S.1011. (In Russian).

[9] Kuznetsova Ye.A., Mikhina T.V. Metodologicheskiye podkhody k formirovaniyu reytinga po urovnyu soblyudeniya trudovogo zakonodatel'stva [Approaches to assessing the efficiency of the industrial safety management system] // Yevraziyskiy Soyuz Uchenykh. 2017. №10-2 (43). (In Russian). 


\section{Materials of International Practical Internet Conference "Challenges of Science”}

[10] Loginov A. K., Lyakhovskiy G. V., Kravchuk I. L. Podkhody k otsenke effektivnosti funktsionirovaniya sistemy upravleniya promyshlennoy bezopasnost'yu [Approaches to assessing the efficiency of the industrial safety management system] // Gornyy informatsionno-analiticheskiy byulleten' (nauchno-tekhnicheskiy zhurnal), vol. 3, №12, 2007, - S. 138-147. (In Russian).

[11] Makarov R. I., Khorosheva Ye. R., Ogryzkov S. A. Metodika analiza i otsenki effektivnosti funktsionirovaniya sistemy menedzhmenta $\mathrm{v}$ oblasti professional'noy bezopasnosti i okhrany truda [Methods for analyzing and evaluating the effectiveness of the management system in the field of occupational safety and labor protection] // Trudy Mezhdunarodnogo simpoziuma «Nadezhnost' i kachestvo», vol. 1, 2005, pp. 472-475. URL: https://cyberleninka.ru/article/n/metodika-analizai-otsenki-effektivnosti-funktsionirovaniya-sistemy-menedzhmenta-v-oblasti-professionalnoy-bezopasnosti-i-ohrany-truda (data obrashcheniya: 02.10.2020). (In Russian).

[12] Makarov R. I., Khorosheva Ye. R., Oryzkov S. A. Metodika analiza i otsenki effektivnosti funktsionirovaniya sistemy menedzhmenta $\mathrm{v}$ oblasti professional'noy bezopasnosti i okhrany truda [Methods for analyzing and assessing the effectiveness of the management system in the field of occupational safety and labor protection] // Trudy Mezhdunarodnogo simpoziuma «Nadezhnost' i kachestvo», NiKa. 2005. №. 1. S. 472-745. URL: https://cyberleninka.ru/article/n/metodikaanaliza-i-otsenki-effektivnosti-funktsionirovaniya-sistemy-menedzhmenta-v-oblasti-professionalnoy-bezopasnosti-iohrany-truda (data obrashcheniya: 30.09.2020). (In Russian).

[13] Metodika otsenki effektivnosti funktsionirovaniya integrirovannoy sistemy upravleniya okhranoy truda na osnove upravleniya professional'nymi riskami (nauchnoye proizvedeniye) [Methodology for assessing the effectiveness of the functioning of an integrated OSH management system based on occupational risk management (scientific work)] / Avtory: Bisakayev S.G., Dzhumagulova N.G., Yesbenbetova ZH.KH., Tanabayeva A.Ye., Aytkenova G.T. / Sv.9304 ot «17» aprelya 2020. (In Russian).

[14] Nikulin A.N., Dolzhikov I.S. Kriterii otsenki effektivnosti funktsionirovaniya sistemy upravleniya okhranoy truda [Criteria for evaluating the effectiveness of the functioning of the occupational safety management system] // Problemy Nauki. 2017. №7 (89). (In Russian).

[15] Pustovit A.Ye., Kozlov V. I. Metodika rascheta indeksa bezopasnosti truda [Methodology for calculating the index of labor safety] // Vestnik KuzGTU. 2013. №3. S. 65-68. URL: https://cyberleninka.ru/article/n/metodika-rascheta-indeksabezopasnosti-truda (data obrashcheniya: 30.09.2020). (In Russian).

[16] Starikov A.V., Khlestkova U.A. Kompleksnyye kriterii otsenki effektivnosti slozhnykh sistem organizatsionnogo upravleniya okhranoy truda i promyshlennoy bezopasnost'yu [Complex criteria for assessing the effectiveness of complex systems of organizational management of labor and industrial safety] // Innovatsionnaya nauka. 2015. №9. S. 97-99. URL: https://cyberleninka.ru/article/n/kompleksnye-kriterii-otsenki-effektivnosti-slozhnyh-sistem-organizatsionnogoupravleniya-ohranoy-truda-i-promyshlennoy-bezopasnostyu (data obrashcheniya: 30.09.2020). (In Russian).

[17] Filimonov V.A., Gorina L.N. Osobennosti razrabotki sistemy upravleniya okhranoy truda na osnove protsessnogo podkhoda [Features of the development of an occupational safety management system based on the process approach] // Zapiski Gornogo instituta. 2019. №. URL: https://cyberleninka.ru/article/n/osobennosti-razrabotki-sistemy-upravleniya-ohranoytruda-na-osnove-protsessnogo-podhoda (data obrashcheniya: 30.09.2020). (In Russian). 